\title{
Analisis Faktor-faktor yang Mempengaruhi Mahasiswa Memanfaatkan Layanan Penelusuran
}

\author{
Indah Wijaya Antasari \\ UPT Perpustakaan IAIN Purwokerto \\ E-mail: indah@iainpurwokerto.ac.id
}

\begin{abstract}
The information retrieval services is a service that interests university library users. There is a significant increase of students completing their thesis using searching services during the COVID-19 pandemic. This study aims to find factors in the utilization of research searching services. It is Using a quantitative approach with exploratory factor analysis (EFA). The study population was 376 students who submitted searching services during the pandemic (March-December 2020), using Slovin formula get a sample 82 respondents. The primary data source from the questionnaire. The results showed that only one (1) factor for the variable use of research searching services, with seven (7) statements: P1, P2, P3, P4, P5, P6, and P7, but, the P8 idea is not continued for analysis because the results of the commonalities test showed that the extraction value is less than 0.5 . The conclusion is the factor variables that influence IAIN Purwokerto students to use the searching service have no dimension (there is only one factor) that is factors for completing thesis, indicators of these factors are seven statements: requires an example of a thesis; enriches material for a thesis; knows how to describe the background; looks for the right theory; gets an appropriate research method; knows how I should explain the discussion; and knows how to conclude the results of a research.
\end{abstract}

Keywords: Library; Research; Retrieval; Analysis; Thesis.

\begin{abstract}
Abstrak
Layanan penelusuran untuk keperluan penelitian menjadi layanan yang diminati pemustaka perpustakaan perguruan tinggi. Terdapat peningkatan yang signifikan jumlah mahasiswa yang sedang menyelesaikan skripsi memanfaatkan layanan penelusuran selama pandemi COVID-19. Kajian ini bertujuan untuk menemukan faktor-faktor dalam pemanfaatan layanan penelusuran penelitian. Menggunakan pendekatan kuantitatif dengan exploratory factor analysis (EFA). Populasi penelitian adalah mahasiswa yang mengajukan layanan penelusuran selama pandemi (Maret-Desember 2020) sejumlah 376, menggunakan rumus Slovin diperoleh sampel sejumlah
\end{abstract}

Tik Ilmeu : Jurnal Ilmu Perpustakaan dan Informasi

IAIN Curup | p-issn: 2580-3654; e-issn:2580-3662

DOI: $10.29240 /$ tik.v5i2.2777 
82 responden. Sumber data penelitian berasal dari kuesioner. Pernyataan yang dapat dilakukan analisis faktor adalah 7 yaitu P1 sampai P7, sedangkan P8 tidak dilanjutkan untuk dilakukan analisis dikarenakan hasil tes communalities menunjukkan nilai extraction kurang dari 0,5. Hasil analisis faktor menunjukkan bahwa hanya terdapat satu (1) faktor yang mempengaruhi mahasiswa IAIN Purwokerto memanfaatkan layanan penelusuran, yaitu faktor menyelesaikan tugas akhir skripsi yang indikatornya adalah memerlukan contoh skripsi; memperkaya bahan untuk skripsi; mengetahui bagaimana menguraikan latar belakang; mencari teori yang tepat; mendapatkan metode penelitian yang sesuai; mengetahui bagaimana saya harus memaparkan pembahasan; dan mengetahui bagaimana menyimpulkan hasil sebuah penelitian.

Kata Kunci: Perpustakaan; Penelitian; Penelusuran; Analisis; Skripsi.

\section{A. PENDAHULUAN}

Pandemi COVID-19 yang melanda dunia sejak tahun 2019 lalu menyebabkan banyak perubahan pola kehidupan. Layanan pendidikan dari PAUD hingga perguruan tinggi lebih banyak dilakukan secara daring. Kegiatan belajar mengajar, kegiatan penelitian dan kegiatan layanan akademik meminimalkan adanya tatap muka langsung (luar jaringan). Tatap muka hanya untuk keperluan tertentu yang tidak bisa dilakukan secara daring. Demikian pula layanan perpustakaan perguruan tinggi melakukan penyesuaian dalam memberikan layanan kepada pemustakanya, yaitu dengan lebih banyak memberikan layanan secara daring.

Perpustakaan IAIN Purwokerto sebagai bagian dari perpustakaan perguruan tinggi memberikan layanan administrasi, sirkulasi, layanan koleksi kitab, layanan referensi secara daring. Layanan penelusuran hasil penelitian ditangani oleh petugas layanan referensi melalui form online (pengajuan/permintaannya) dan jawaban pustakawan melalui aplikasi whatsapp, telegram, atau e-mail. Mahasiswa memerlukan bantuan pustakawan untuk memenuhi keperluan penyelesaian tugas-tugas kuliahnya, terlebih bagi mahasiswa yang belum paham bagaimana pencarian bahan rujukan. Menurut data layanan penelusuran informasi Perpustakaan IAIN Purwokerto tahun 2017-2020, selama pandemi jumlah permintaan layanan penelusuran daring mengalami peningkatan jika dibandingkan sebelum pandemi (layanan penelusuran luring). 
Data permintaan layanan penelusuran tahun 2017 menunjukkan ada 140 permintaan (Antasari, 2020), tahun 2018 terdapat 40 permintaan, tahun 2019 terdapat 15 permintaan (sumber: dokumen layanan). Bulan JanuariFebruari 2020 terdapat 20 permintaan dan selama pandemi di Indonesia (Maret-Desember 2020) terdapat 450 permintaan layanan penelusuran. Adanya peningkatan jumlah permintaan layanan penelusuran di Perpustakaan IAIN Purwokerto secara online selama pandemi COVID-19, dirasakan juga oleh Walsh dan Rana (2020) yang mengatakan bahwa selama pandemi permintaan layanan jarak jauh (Online) di Perpustakaan Universitas Toronto telah mengalami peningkatan dan signifikan untuk mendukung penelitian (Walsh \& Rana, 2020).

Menurut Peraturan Kepala Perpustakaan Nasional RI Nomor 12 Tahun 2018 tentang Pedoman Penilaian Angka Kredit Unsur Pelayanan Perpustakaan, layanan penelusuran di perpustakaan terdiri dari:

1. Layanan penelusuran sederhana adalah kegiatan layanan penelusuran informasi tentang suatu subjek dengan menggunakan sarana temu kembali informasi yang tersedia di perpustakaan sesuai kebutuhan pemustaka (Perpusnas RI, 2017, p. 89).

2. Layanan penelusuran informasi kompleks adalah kegiatan layanan penelusuran informasi khusus tentang suatu subjek dengan menggunakan sarana temu kembali informasi yang tersedia di dalam atau di luar perpustakaan (Perpusnas RI, 2017, p. 220).

Penelitian ini membahas layanan penelusuran kompleks (khusus untuk keperluan penelitian mahasiswa). Delaney and Bates (2018) menemukan bahwa mayoritas (90\% responden) mahasiswa berpendapat bahwa layanan perpustakaan sangat penting untuk menunjang proses penelitian mereka (Delaney \& Bates, 2018). Sebuah kajian systematic literature review(SLR) menunjukkan bahwa terjadi peningkatan keterampilan dan kepercayaan diri pada para peneliti setelah mereka berinteraksi dan konsultasi dengan pustakawan (Dalton, 2019). Hal ini dapat menjadi landasan bahwa layanan penelusuran khusus penelitian di perpustakaan perguruan tinggi menjadi layanan yang sangat diperlukan.

Eksplorasi instrumen dilakukan untuk mengetahui sebab-sebab mahasiswa memanfaatkan layanan penelusuran di Perpustakaan IAIN Purwokerto. Hal ini diperlukan agar dapat diketahui instrumen/indikator yang dapat digunakan untuk mengembangkan penelitian-penelitian layanan di perpustakaan perguruan tinggi. Berdasarkan hal tersebut, penelitian ini bermaksud melakukan analisis instrumen untuk variabel pemanfaatan layanan penelusuran kompleks di perpustakaan IAIN Purwokerto dengan metode exploratory factor analysis. Rumusan masalahnya adalah: Ada berapa faktor 
dalam variabel pemanfaatan layanan penelusuran? dan Faktor apa saja yang terbentuk?

Penelitian menggunakan pendekatan kuantitatif. Analisis faktor merupakan alat statistika yang dapat digunakan untuk mereduksi variabel dari kumpulan variabel dengan cara membangun interkorelasi pada sekumpulan variabel data tersebut (Pramesti, 2014, p. 161). Senada dengan pendapat Brown (2006) yang mengatakan bahwa A factor is an unobservable variable that influences more than one observed measure and that accounts for the correlations among these observed measures. Penelitian ini menggunakan Exploratory Factor Analysis (EFA), yang didefinisikan oleh Samuels (2017) sebagai proses yang dapat dilakukan pada aplikasi SPSS untuk memvalidasi item dalam kuesioner (Samuels, 2017, p. 1). Metode extraction menggunakan metode Principal Component Analysis (CPA).

Populasi adalah mahasiswa S1 yang memanfaatkan layanan penelusuran untuk keperluan skripsi selama masa pandemi tahun 2020 (Maret-Desember) yaitu sejumlah 376 mahasiswa. Semua mahasiswa mempunyai peluang menjadi responden, setelah kuesioner dalam bentuk google form disebarkan terdapat 82 mahasiswa yang mengisi kuesioner. Jika mengacu pada rumus Slovin dengan nilai error 10\%, maka jumlah sampel minimal adalah 376: $1(376 \times 10 \%)=79$. Penelitian ini dilanjutkan karena dinilai memenuhi syarat sampel, didukung oleh McNeish (2017) yang menjelaskan bahwa antara 40-60\% penelitian Exploratory Factor Analysis (EFA) menggunakan sampel kecil (di bawah 200) (McNeish, 2017).

Teknik Exploratory Factor Analysis cocok untuk membuktikan apakah variabel pemanfaatan layanan penelusuran mempunyai faktor, dimana butir pernyataannya berasal dari tahapan eksplorasi (bukan menguji teori/model/konsep yang sudah ada sebelumnya). Butir pernyataan dalam kuesioner merupakan hasil eksplorasi melalui tanya jawab pada saat memberikan layanan penelusuran kepada mahasiswa. Beberapa jawaban pemustaka dapat diklasifikasikan dalam beberapa pernyataan. Delapan pernyataan berikut dianggap dapat mewakili jawaban-jawaban pemustaka. Pernyataan yang mencerminkan mengapa mahasiswa memanfaatkan layanan penelususran, antara lain:

P1: Memerlukan contoh skripsi atau penelitian sebelumnya dengan tema yang sama dengan skripsi saya;

P2: Ingin memperkaya bahan untuk skripsi saya;

P3: Ingin mengetahui bagaimana menguraikan latar belakang/pendahuluan dalam penelitian/skripsi;

P4: Mencari teori yang tepat untuk skripsi saya; 
P5: Untuk mendapatkan metode penelitian yang sesuai skripsi saya

P6: Untuk mengetahui bagaimana saya harus memaparkan pembahasan dalam skripsi saya

P7: Untuk mengetahui bagaimana menyimpulkan hasil sebuah penelitian;

P8: Menemui titik jenuh dalam mengerjakan skripsi dan memerlukan bantuan orang lain.

Namun dalam tes communalities, nilai extraction dari P8 kurang dari 0,5 sehingga pernyataan ke-8 ini tidak dapat diteruskan karena tidak memenuhi syarat. Setelah P8 dihapus, selanjutnya analisis faktor menggunakan tujuh (P1-P7) butir pernyataan yang diulas dalam hasil dan pembahasan. Penelitian menggunakan aplikasi SPSS versi 25 sebagai alat bantu olah data.

\section{B. HASIL DAN PEMBAHASAN}

\section{Identitas Responden}

Responden adalah mahasiswa S1 yang telah mengajukan permintaan layanan penelusuran secara daring selama Maret-Desember 2020. Responden angkatan 2016 berarti pada tahun 2020 berada pada semester 8-9 yang pada umumnya mahasiswa sedang menyelesaikan tugas skripsinya. Angkatan 2013 merupakan angkatan tertua yang mengajukan layanan penelusuran. Adapun angkatan 2017 yang notabene tahun 2020 berada pada semester 6-7, sebagai persiapan sebelum mengambil mata kuliah skripsi di semester 8 sesuai panduan akademik IAIN Purwokerto (Warsito et al., 2019). Data penelitian menunjukkan bahwa jumlah responden berasal dari tahun angkatan 2013 (2 pemustaka); 2015 (3 pemustaka); 2016 (62 pemustaka); dan 2017 (15 pemustaka).

Sebaran responden berasal dari lima fakultas yang berbeda, sebagai berikut: FTIK terdapat 46; F Dakwah terdapat 4; F Syariah terdapat 15; F Ekonomi Bisnis (FEBI) terdapat 15; dan FUAH ada 2 pemustaka. Responden terbanyak dari Fakultas Tarbiyah (FTIK), dan paling sedikit dari Fakultas Ushuluddin, Adab dan Humaniora (FUAH). FEBI dan FUAH merupakan fakultas baru yang terbentuk bedasarkan peraturan menteri agama nomor 3 tahun 2015 tentang Organisasi Dan Tata Kerja pasal 11, yang menjelaskan bahwa fakultas pada IAIN Purwokerto terdiri dari: Tarbiyah dan Ilmu Keguruan; Syariah; Dakwah; Ushuluddin, Adab, dan Humaniora; dan Ekonomi dan Bisnis Islam (Kementerian Agama RI, 2015). Sebelumnya, saat menjadi STAIN belum ada FEBI dan FUAH. 


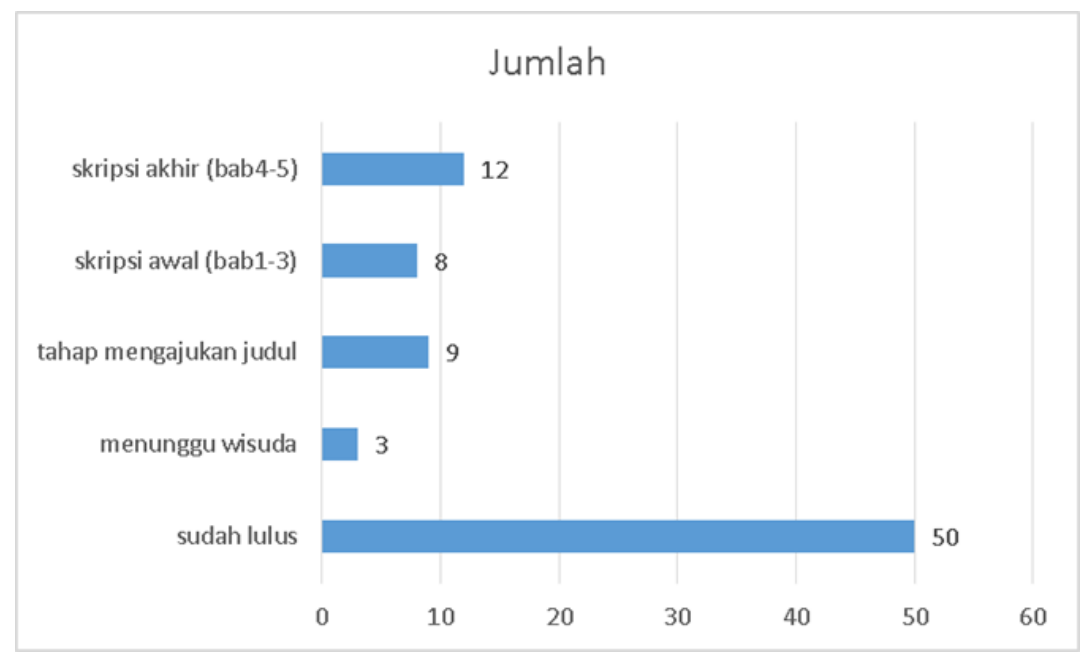

Gambar 1. Posisi Penyelesaian Skripsi

Sumber: data penelitian, 2021

Penyebaran kuesioner dilakukan selama bulan April 2021, dengan keadaan sejumlah 50 responden berstatus sudah lulus (menerima ijazah) dan 3 responden yang menunggu wisuda (sudah lulus). Mahasiswa yang masih mempunyai waktu panjang untuk mengerjakan skripsi ada 17 responden (tahap pengajuan judul ditambah tahap skripsi awal (bab 1-3). Responden yang sudah mempunyai harapan lulus dalam waktu dekat (skripsi tahap akhir) ada 12. Data ini menunjukkan bahwa mahasiswa yang mengajukan layanan penelusuran kompleks pada masa pandemi 2020 banyak yang sudah lulus. Namun 17 mahasiswa yang masih tahap awal ini perlu diperhatikan kembali apakah karena ada kesulitan mencari bahan rujukan atau tidak.

Terdapat responden angkatan 2013 yang sudah lulus semua ( $2 \mathrm{mhs}$ ), namun mahasiswa angkatan 2015 belum lulus (3 mhs). Angkatan atas (semester 9 keatas memerlukan kajian yang lebih mendalam bagaimana layanan perpustakaan dapat membantu penyelesaian skripsinya.

\section{Uji Persyaratan}

Analisis faktor dapat dilanjutkan dengan melalui syarat uji sebelumnya. Adapun persyaratannya antara lain:

1. Nilai Kaiser-Mayer-Olkin Measure of Sampling Adequacy (KMO-MSA) > 0,50 dan nilai Bartlett's Test of Sphericity(Sig.) < 0,05.

2. Ada korelasi yang kuat antar variabel. Hal ini dapat terlihat pada nilai Anti Image Correlation antar variabel $>0,50$. 
Tabel 1. KMO and Bartlett's Test

\begin{tabular}{lrr}
\hline $\begin{array}{l}\text { Kaiser-Meyer-Olkin Measure of Sampling } \\
\text { Adequacy. }\end{array}$ & 0,864 \\
\hline & Approx. Chi-Square & 420,987 \\
Bartlett's Test of & & \\
Sphericity & df & 21 \\
& Sig. & 0 \\
\hline
\end{tabular}

Sumber: hasil olah data penelitian, 2021

Jika nilai KMO-MSA lebih besar dari 0,50 maka teknik analisis faktor dapat dilanjutkan. Berdasarkan output Tabel 1 diketahui bahwa nilai KMO-MSA sebesar 0,864 > 0,50 dan nilai Bartlett's Test of Sphericity (Sig.) $0,000<0,05$ sehingga analisis faktor dapat dilanjutkan karena sudah memenuhi persyaratan.

Tabel 2. Anti-image Matrices

\begin{tabular}{|c|c|c|c|c|c|c|c|c|}
\hline & & P1 & P2 & P3 & P4 & P5 & P6 & P7 \\
\hline \multirow{7}{*}{$\begin{array}{l}\text { Anti-image } \\
\text { Covarianc } \\
\text { e }\end{array}$} & P1 & 0,39 & $-0,115$ & $-0,03$ & $-0,095$ & $-0,042$ & 0,006 & 0,007 \\
\hline & P2 & $-0,115$ & 0,291 & $-0,083$ & $-0,064$ & $-0,009$ & $-0,111$ & 0,093 \\
\hline & P3 & $-0,03$ & $-0,083$ & 0,337 & 0,014 & $-0,102$ & 0,005 & $-0,114$ \\
\hline & P4 & $-0,095$ & $-0,064$ & 0,014 & 0,323 & $-0,119$ & $-0,051$ & 0,023 \\
\hline & P5 & $-0,042$ & $-0,009$ & $-0,102$ & $-0,119$ & 0,314 & 0,005 & $-0,063$ \\
\hline & P6 & 0,006 & $-0,111$ & 0,005 & $-0,051$ & 0,005 & 0,261 & $-0,175$ \\
\hline & P7 & 0,007 & 0,093 & $-0,114$ & 0,023 & $-0,063$ & $-0,175$ & 0,328 \\
\hline \multirow{7}{*}{$\begin{array}{l}\text { Anti-image } \\
\text { Correlation }\end{array}$} & P1 &, $916^{\mathrm{a}}$ & $-0,341$ & $-0,084$ & $-0,267$ & $-0,12$ & 0,018 & 0,019 \\
\hline & $\mathrm{P} 2$ & $-0,341$ &, $841^{\mathrm{a}}$ & $-0,266$ & $-0,208$ & $-0,03$ & $-0,403$ & 0,302 \\
\hline & P3 & $-0,084$ & $-0,266$ &, $897^{\mathrm{a}}$ & 0,044 & $-0,313$ & 0,018 & $-0,344$ \\
\hline & P4 & $-0,267$ & $-0,208$ & 0,044 &, $898^{\mathrm{a}}$ & $-0,375$ & $-0,175$ & 0,069 \\
\hline & P5 & $-0,12$ & $-0,03$ & $-0,313$ & $-0,375$ &, $902^{\mathrm{a}}$ & 0,016 & $-0,198$ \\
\hline & P6 & 0,018 & $-0,403$ & 0,018 & $-0,175$ & 0,016 &, $830^{\mathrm{a}}$ & $-0,597$ \\
\hline & P7 & 0,019 & 0,302 & $-0,344$ & 0,069 & $-0,198$ & $-0,597$ & $.765^{\mathrm{a}}$ \\
\hline
\end{tabular}

Sumber: hasil olah data penelitian, 2021

Anti image matrices berguna untuk mengetahui dan menentukan variabel mana saja yang layak pakai dalam analisis faktor. Pada Tabel 2 terdapat huruf "a" yang artinya tanda untuk Measure of Sampling Adequacy (MSA). Diketahui nilai MSA masing-masing yang diteliti adalah: 0,916; 0,$841 ; 0,897 ; 0,898 ; 0,902 ; 0,830$; dan 0,765 . 
Persyaratan yang harus dipenuhi dalam analisis faktor adalah nilai MSA > 0,50. Dari hasil tabel 2 dapat diketahui jika semua butir pernyataan mempunyai nilai MSA>0,50 sehingga memenuhi syarat untuk dilakukan analisis faktor.

Tabel 3. Communalities

\begin{tabular}{lcr}
\hline & Initial & \multicolumn{2}{c}{ Extraction } \\
\hline P1 & 1 & 0,643 \\
P2 & 1 & 0,71 \\
P3 & 1 & 0,718 \\
P4 & 1 & 0,716 \\
P5 & 1 & 0,749 \\
P6 & 1 & 0,739 \\
P7 & 1 & 0,555 \\
\hline \multicolumn{2}{l}{ Extraction Method: Principal } \\
Component Analy sis.
\end{tabular}

Sumber: hasil olah data penelitian, 2021.

Tabel 3 menunjukkan nilai butir yang diteliti apakah mampu menjelaskan faktor atau tidak. Butir dianggap mampu menjelaskan faktor jika nilai extraction $>0,50$.

\section{Analisis Faktor}

Jumlah faktor yang terbentuk dapat diketahui dengan melihat Tabel 4. Total Varian Explained. Jika nilai total eigenvalues component lebih dari 1 maka dapat berdiri sendiri sebagai faktor. Adapun jika nilai total eigenvalues component kurang dari satu (1) maka kontribusi kepada faktor yang diikutinya dapat dilihat pada Tabel 5. Component Matrices. 


\section{Tabel 4. Total Variance Explained}

\begin{tabular}{|c|c|c|c|c|c|c|}
\hline \multirow[b]{2}{*}{ Component } & \multicolumn{3}{|c|}{ Initial Eigenvalues } & \multicolumn{3}{|c|}{ Extraction Sums of Squared Loadings } \\
\hline & Total & $\begin{array}{c}\% \text { of } \\
\text { Variance }\end{array}$ & $\begin{array}{c}\text { Cumulative } \\
\%\end{array}$ & Total & $\begin{array}{c}\% \text { of } \\
\text { Variance }\end{array}$ & $\begin{array}{c}\text { Cumulative } \\
\%\end{array}$ \\
\hline 1 & 4,831 & 69,021 & 69,021 & 4,831 & 69,021 & 69,021 \\
\hline 2 & 0,787 & 11,248 & 80,269 & & & \\
\hline 3 & 0,396 & 5,654 & 85,923 & & & \\
\hline 4 & 0,344 & 4,911 & 90,835 & & & \\
\hline 5 & 0,294 & 4,197 & 95,032 & & & \\
\hline 6 & 0,202 & 2,887 & 97,92 & & & \\
\hline 7 & 0,146 & 2,08 & 100 & & & \\
\hline
\end{tabular}

Extraction Method: Principal Component Analy sis.

Sumber: hasil olah data penelitian 2021

Tabel 4 menunjukkan nilai masing-masing pernyataan yang dianalisis. Ada tujuh (7) pernyataan yang menunjukkan sebab mahasiswa mengajukan layanan penelusuran (rujukan untuk skripsi) yang berarti ada 7 komponen yang dianalisis. Ada dua macam analisis untuk menjelaskan suatu varian yaitu Initial Eigenvalues dan Extraction Sums of Squared Loading. Pada varian Initial Eugenvalues menunjukkan faktor yang terbentuk, sedangkan pada Extraction Sums of Squared Loading menunjukkan jumlah variasi atau banyaknya faktor yang dapat terbentuk.

Tabel 4 menunjukkan bahwa ada 1 variasi faktor yaitu 4,831 yang bisa menjelaskan 69,021\% variasi. Nilai komponen $2,3,4,5,6,7,8$, tidak dihitung karena nilai eugenvalues kurang dari satu $(<1)$ sehingga tidak menjadi sebuah faktor. 
Tabel 5. Component Matrix ${ }^{\mathrm{a}}$

\begin{tabular}{lr}
\hline \multicolumn{2}{c}{ Component } \\
\hline P5 & 0,865 \\
P6 & 0,86 \\
P3 & 0,848 \\
P4 & 0,846 \\
P2 & 0,842 \\
P1 & 0,802 \\
P7 & 0,745 \\
\hline
\end{tabular}

Extraction Method: Principal

Component Analysis.

a. 1 components extracted.

Sumber: hasil olah data penelitian 2021

Component Matrix ini menunjukkan nilai korelasi antara masingmasing variabel dengan faktor yang terbentuk. Tabel 5 menunjukkan bahwa pernyataan P5 "untuk mendapatkan metode penelitian yang sesuai skripsi saya" mempunyai nilai korelasi sebesar 0,865 terhadap faktor. P1 sampai P7 mempunyai korelasi yang baik dengan nilai korelasi yang tinggi diatas 0,7 semua. Jadi dapat dikatakan bahwa semua butir pernyataan mempunyai korelasi yang kuat terhadap faktornya.

Layanan penelusuran yang berbasis temu kembali informasi (information retrieval) sangat diperlukan mahasiswa, seperti yang dijelaskan (Buckland, 2014) bahwa terdapat lima (5) hal yang menyebabkan layanan berbasis temu kembali informasi diperlukan: Inquiry, adanya rasa ingin tahu atau ketidaktahuan yang mengganggu; Temu kembali (Retrieval) dapat dilihat sebagai tanggapan atas pertanyaan; Becoming informed, proses dimana pengetahuan pribadi orang menyebabkan perubahan dalam menanggapi pesan yang mereka terima; The Demand, merupakan respon terhadap kebutuhan dan persepsi tentang peluang melakukan sesuatu untuk memenuhi kebutuhan itu; The Allocation of Resources, sumber daya perpustakaan untuk dialokasikan dalam penyediaan layanan.

Layanan daring sangat membantu mahasiswa dalam keadaan pandemi ini. Senada dengan pendapat Setiawan (2017) yang menyatakan bahwa untuk membantu mengurangi kecemasan kebutuhan informasi para 
pemustaka dalam penelusuran informasi, diantaranya dapat dilakukan dengan menyediakan layanan virtual reference . Layanan penelusuran kompleks dalam hal ini masuk dalam kategori rujukan untuk penelitian. Perpustakaan mempunyai peran yang strategis dalam membantu mahasiswa melakukan penelitian, hal didukung oleh Delaney dan Bates (2018) yang menemukan bahwa $90 \%$ responden sangat setuju bahwa layanan perpustakaan universitas penting untuk menyelesaikan penelitian mereka (Delaney \& Bates, 2018) .

Hasil penelitian ini menguatkan penelitian Asmawan (2017) yang menyebutkan bahwa kemampuan merumuskan masalah; menentukan judul; membuat latar belakang masalah; menentukan tujuan dan manfaat penelitian; menentukan metode penelitian; mencari data atau sumber data yang terkait; menuliskan data dalam skripsi; menulis pembahasan dan menarik kesimpulan, merupakan kemampuan dalam diri mahasiswa yang sangat menentukan selesainya skripsi.

\section{KESIMPULAN}

Kesimpulan penelitian adalah variabel pemanfaatan layanan penelusuran di Perpustakaan IAIN Purwokerto terdiri dari satu (1) faktor. Variabel pemanfaatan layanan penelusuran tidak memiliki dimensi, artinya langsung berisi variabel manifesnya (butir pernyataan/instrumen). Faktor yang terbentuk oleh tujuh (7) butir pernyataan menunjukkan bahwa mahasiswa mengajukan layanan penelusuran untuk membantu menyelesaikan tugas skripsinya dari mulai proses penyusunan proposal hingga pelaporan hasil penelitian.

\section{DAFTAR RUJUKAN}

Antasari, I. W. (2020). Layanan Penelusuran Kompleks Berbasis Teknologi Informasi di Perpustakaan. Al-Ma'mun: Jurnal Kajian Kepustakawanan Dan Informasi, 1(1), 1-10. https://doi.org/10.24090/jkki.v1i1.4049

Asmawan, A. (2017). Analisis kesulitan mahasiswa menyelesaikan skripsi. Jurnal Pendidikan Ilmu Sosial, 26(2), 51-57. https://doi.org/10.2317/jpis.v26i2.3331

Brown, T. A. (2006). Confirmatory Factor Analysis for Applied Research. Guilford Press.

Buckland, M. K. (2014). Library services in theory and context. Elsevier. 
Dalton, M. (2019). How individual consultations with a librarian can support systematic reviews in the social sciences. Journal of Information Literacy, 13(2), 163. https://doi.org/10.11645/13.2.2621

Delaney, G., \& Bates, J. (2018). How can the university library better meet the information needs of research students? Experiences from Ulster University. New Review of Academic Librarianship, 24(1), 63-89. https://doi.org/doi.org/10.1080/13614533.2017.1384267

Kementerian Agama RI. (2015). Peraturan Menteri Agama Republik Indonesia Nomor 3 Tahun 2015 Tentang Organisasi Dan Tata Kerja Institut Agama Islam Negeri Purwokerto. Kementerian Agama RI. https://simpuh.kemenag.go.id/regulasi/pma_03_15.pdf

McNeish, D. (2017). Exploratory factor analysis with small samples and missing data. Journal of Personality Assessment, 99(6), 637-652. https://doi.org/doi.org/10.1080/00223891.2016.1252382

Perpusnas RI. (2017). Peraturan Kepala Perpustakaan Nasional RI Nomor 12 Tahun 2018 tentang Pedoman Penilaian Angka Kredit Unsur Pelayanan Perpustakaan. Perpustakaan Nasional RI.

Pramesti, G. (2014). Kupas Tuntas Data Penelitian dengan SPSS 22. Elex Media Komputindo.

Samuels, P. (2017). Advice on exploratory factor analysis (Birmingham City University). Center for Academic Success.

Setiawan, M. V. (2017). Mengurangi kecemasan pemustaka dalam proses penelusuran informasi melalui layanan virtual referens di perpustakaan perguruan tinggi. Berkala Ilmu Perpustakaan Dan Informasi, 13(2), 178-190. https://doi.org/doi.org/10.22146/bip.27224

Walsh, B., \& Rana, H. (2020). Continuity of Academic Library Services during the Pandemic The University of Toronto Libraries' Response. Journal of Scholarly Publishing, 51(4), 237-245. https://doi.org/10.3138/jsp.51.4.04

Warsito, C., Masmin Afif, Rohmad, Suparjo, Ahmad Sidiq, Muskinul Fuad, Ahmad Dahlan, Hartono, Hizbul Muflihin, Kholil Lur Rohman, Safruddin Aziz, M. Fadlan, Rofina Dienasari, M. Aqil Muzakki, \& Dicki Hananto Wibowo. (2019). Panduan Akademik Program Strata Satu (S-1) Institut Agama Islam Negeri Purwokerto Tahun Akademik 2019-2020. IAIN Purwokerto. 
Tik Ilmeu, Vol.5, No.2, 2021 | 185

Watkins, M. W. (2018). Exploratory factor analysis: A guide to best practice. Journal of Black Psychology, 44(3), 219-246. https://doi.org/10.1177/0095798418771807 